\title{
Ecology factor and Venom of snake Macrovipera lebetina obtusa
}

\author{
Sh.A. Topchiyeva, H.A. Abiyev, E.T.Babayev \\ Institute of Zoology of NAS of Azerbaijan, Baku \\ Address: AZ1073, Baku, Sabail, Abbasgulu Abbaszadeh, 115 \\ e-mail.: shafiga.topchiyeva@mail.ru
}

\begin{abstract}
In this article presents experimental data, the basic composition of the venom of Macrovipera lebetina obtusa, captured from different regions of Azerbaijan, differing in degree of contamination by industrial emissions was studied. $\gamma$ - radiospectrometric studies showed that the samples of venom also contain radionuclides as Ra228, Ra226, K40 and 137 Cs. It was established that the radiation dose (up to dose $1.35 \mathrm{kGy}$ ) for 3 minutes did not cause structural changes in the samples venom of vipera, but rather contribute to the stabilization of both toxicity and pharmacological activity while increasing the shelf life of aqueous solutions of vipera venom. At high doses (2.7, 4.05 and $5.4 \mathrm{kGy}) \gamma$ irradiation for 3 minutes there was a gradual decrease in toxicity (pharmacological activity of enzymes) of snake venom. We can assume that these data can be used in the identification of zootoxins and their metabolites, and these criteria can serve as a theoretical basis for the development of effective methods for diagnosis of poisoning zootoxins.
\end{abstract}

Keywords-snake, venom, Macroipera lebetina obtusa, Ecology factor radionuclides, radiation dose.

\section{INTRODUCTION}

One of the global problems is the study of the influence of environmental factors on snake venoms [20, 21].

Relative density of venom of the cobra which's value corresponded 1.084 was experimentally defined. It was noticed, that reaction of snake venoms -is sour. Water solutions of snake venom are unstable and lost toxicity in some days after mixing. The toxicity of snake venoms (Echis carinatus, Vipera lebetina obtusa, Naja naja) in the physiological solution containing $50 \%$ of glycerin, at storage in a refrigerator within 6 months did not get reduced In this research the influence of environmental factors on snake venoms was revealed. It should be noted that snake venom only after drying over calcium chloride vapors or after liofil drying, retains pharmacological and toxicological properties. Venom of a cobra, at storage on a cold in the soldered ampoule kept toxicity more than 20 years. Snake venoms are thermostable in the sour environment and can withstand heating up to $120^{\circ} \mathrm{C}$ without loss of activity $[12,14,15]$.

Some chemical agents, such as potassium permanganate, chloroform, ethanol, methyl-blue, have a destructive effect on poisons. The activation of snake venoms occurs under the influence of some physical factors, for example, under the influence of ultraviolet irradiation and X-rays [12]. So, in 7 days after a venom irradiation of Filipina cobras by $\gamma$ radiation $\left({ }^{60} \mathrm{Co}\right)$ in doses $0.25,0.5,1 \mathrm{mrad}$, toxicity of snake venom made 83,66 and $43 \%$, accordingly from not irradiated venom $[16,17,18]$.

On literary data snake venom in the dried up kind keeps pharmacological and toxic properties till 22 years and even more. At cultivation of venom by water by physiological solution or glycerin, toxic properties of snake venoms are not lost. Short-term influence of heat also does not render essential influence on toxicity of venom. Considerable influence on toxicity and quantity of allocated venom is rendered by various biological, ecological factors, and also chemical agents and some physical factors [22, 23, 24, 19].

Small doses of venom do not cause any clinical displays of a venoming and long ago was used at treatment of many serious illnesses.Venom of Vipera lebetina renders anti-inflammatory and analgeting action. It is considered possible to use of venoms of Vipera libetina, Echis carinatus and cobras in otolaryngology $[12,13]$.

Snake venoms are a great value for medicine and biology. Snake venoms are used at preparation of monoand polyvalent whey. Venom of Vipera libetina is applied as blood stopping means in otoloringology at operations during removing of glands, at nasal bleedings etc. [1, 4, 5, $7,8]$. Influence of ecological factors on a chemical compound of venom Caucasian Vipera lebetina obtusa was revealed. Elementary structure of venom of Vipera lebetina obtusa caught from the various areas of Azerbaijan polluted by technogenic emissions of the industrial enterprises was studied by the atom -absorption spectrophotometer method. In venom of Vipera lebetina obtusa the maintenance of heavy metals; $\mathrm{Cr}, \mathrm{Pb}, \mathrm{Cd}, \mathrm{Ni}$ and $\mathrm{Zn}$ were defined $[9,10,11]$. Researches on revealing of influence of $\gamma$-radiation on toxicity and on pharmacological properties of venom of Vipera lebetina 
obtusa were carried out [2,3].

Progressing environmental pollution by polutant leads in turn to gradual pauperisation of fauna and flora of the given areas of Azerbaijan. In addition, it directly affects the pharmacological and toxicological activity and, in turn, the chemical structure, biochemical and biophysical properties of the products of the biosynthesis of poisonous animals. 23 kinds of snakes live in territory of Azerbaijan, 4 kinds of them are venomous. Research of toxins of various kinds of snakes, and also huge attention to zootoxins is defined not only by inquiries of medical practice, but their studying and use represents the big interest for various branches of biology, ph Many questions on influence of -radiation and other ionising radiation on a live organism and venom of snakes remain opened. These questions are important for technology of radiating sterilisation of medical products on the basis of venom of snake.

Research objective was studying of influence of biotics and abiotics factors, on biochemical indicators, pharmacological and toxicological properties of venom of Transcaucasian vipera and an establishment of optimal doses of radiation sterilisation of venom.

\section{MATERIAL AND METHODS}

The material of the study was the whole venom of the Macrovipera lebetina obtusa collected in the area of the Azerbaijan. The venom was stored in a desiccator over a couple of calcium chloride.

The maintenance of heavy metals- polluters in venom of vipera caught from ecologically polluted sites of Absheron was defined by the atom-absorbtsion spectrophotometries method (AAS-300, Perkin-Elmer).

As a result, chemical compound changes and also influence of heavy metals on albuminous structure, fermentative activity and other biochemical indicators of venom of viperas was established.

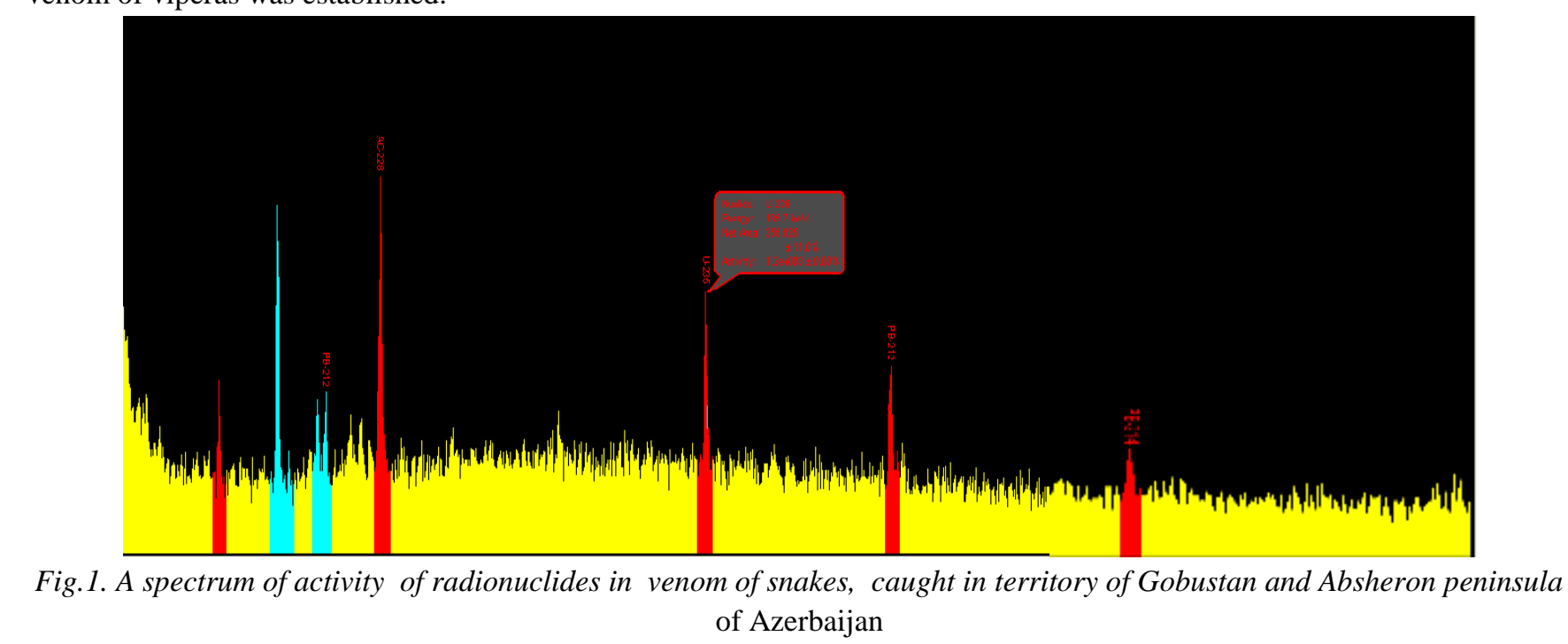

Fig.1. A spectrum of activity of radionuclides in venom of snakes, caught in territory of Gobustan and Absheron peninsula of Azerbaijan
Influences of intensity of electromagnetic radiation on albuminous structure, the maintenance of the general fiber and the change of toxicity of venom of snakes was revealed.ysiology, bioorganic chemistry, biophysics, toxicology and other areas of sciences.

Despite numerous studies on the study of snake venom, a number of questions of which is of great scientific and practical interest. Proceeding from the foregoing, the purpose of these studies was to Experimental researches by influence definition of pollution on biochemical characteristics and toxicity of venom of vipers was carried out.

\section{RESULTS}

We conducted summer field researches in vicinities of Baku, and also in different areas of Azerbaijan: Gobustan, Shamakhi, Kurdamir and Sabirabad. During the expedition catching of viperas was spent with milking venom, taking samples of soil and vegetation. Snakes after milking have been released in the nature, venom was placed in exicators, dried up for analysis carrying out on the maintenance of heavy metals by a method of atom-absorbtion spectrometry. A part of venom of snake was subjected to the analysis on the maintenance of radionuclides on installation Camberra.

We had carried out experimental measurements of the maintenance of radio nuclides in samples of venom of viperas, caught from districts of Azerbaijan with various degree of impurity. The spectrum defining activity of radionuclides in venom of snakes was drawn on spectrometer Camberra. The radiating background of radionuclides (uranium, caesium), defined in venom of snakes is presented in the table 1 , and fig. 1, 2, 3. The radiating background of radionuclides in venom of snakes from various zones was identical. 
Table.1: Radiating activity of elements in investigated samples

\begin{tabular}{|c|c|c|c|}
\hline The crystals were Venom & Sample 1 & Sample 2 & Sample 3 \\
\hline The name radionuclide & $\mathrm{Ra}^{226}$ & $\mathrm{~K}^{40}$ & $\begin{array}{c}\mathrm{Ra}^{226}=\mathrm{Pb}^{212}, \mathrm{U}^{235}, \\
\mathrm{U}^{238}\end{array}$ \\
\hline Energy radionuclide & $186.2 \mathrm{keV}$ & $1460.8 \mathrm{keV}$ & $185.97 \mathrm{keV}$ \\
\hline Radiating activity & $0.539663 \mathrm{Bk} / \mathrm{g}$ & $1.44382 \mathrm{Bk} / \mathrm{g}$ & $5.26 \%$ \\
\hline Radiatsionno-chemical exit & $3.28 \%$ & $10.67 \%$ & 77,770 \\
\hline The peak area with a margin error & $356 ; 10.98 \%$ & $\begin{array}{c}483 \\
4.897 \%\end{array}$ & $55 \mathrm{mg}$ \\
\hline Mass & $56 \mathrm{mg}$ & $60 \mathrm{mg}$ & $0.427,0.26,12.64 \mathrm{Bk} / \mathrm{kg}$ \\
\hline Specific activity & - & - & \\
\hline Width of semiheight & $0.936 \mathrm{keV}$ & $1.501 \mathrm{keV}$ & \\
\hline
\end{tabular}

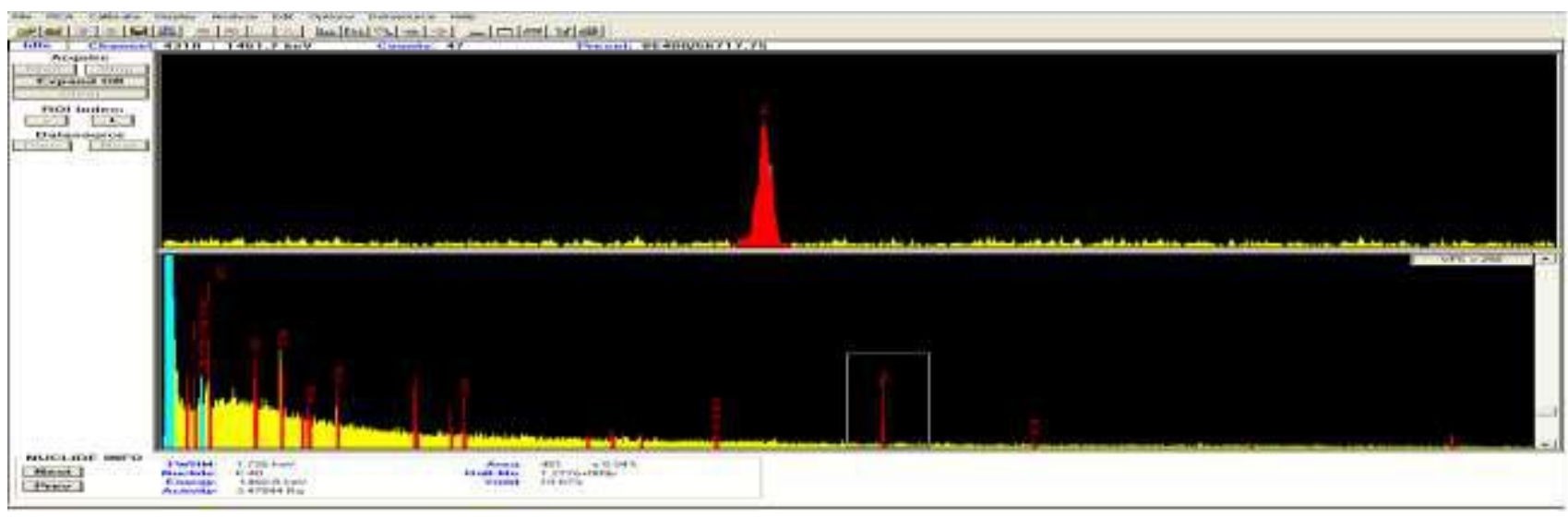

Fig.2: A spectrum of activity of radionuclides in the venom of snakes, caught in territory of Shamakhi of Azerbaijan

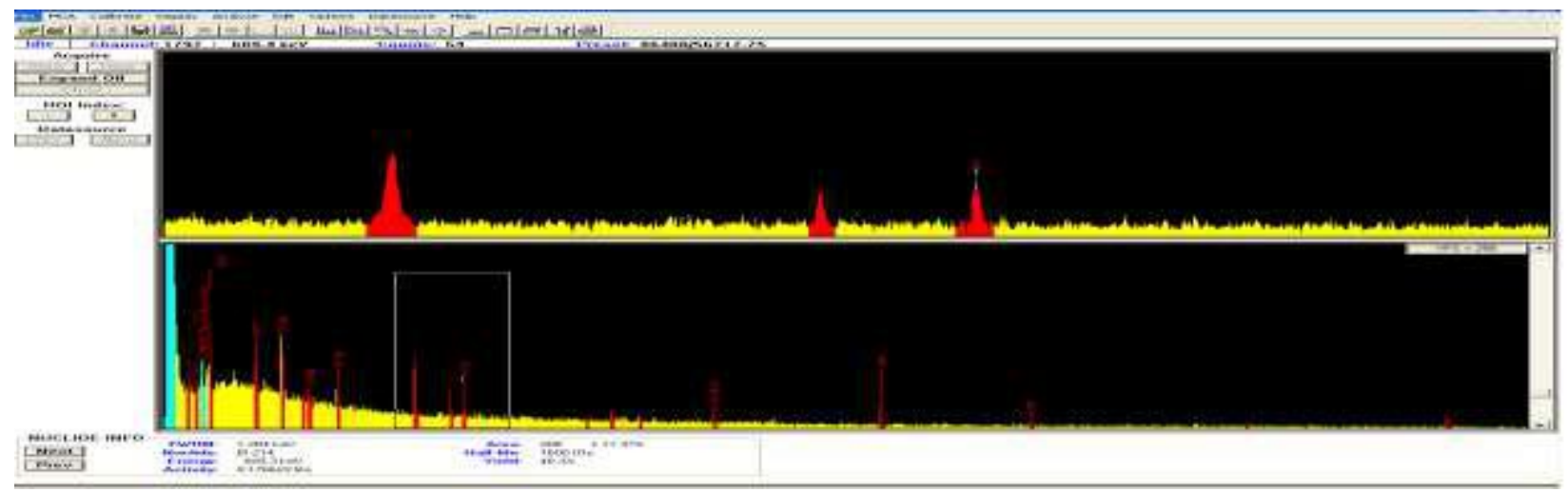

Fig.3: A spectrum of activity of radionuclides in the venom of snakes, caught in territory of Sabirabad and Kurdamir

Research on the influence of EMR on lifespan of envenomed mice were carried out in experiment on threemonthly not purebred white mice with weight of a body 22-25 g. Snake venom was injected into the mice intraperitoneally in a dose of weight of a body of 0.2 $\mathrm{mg} / \mathrm{g}$. We had used 70 mice in experiments. Mice were divided into two groups: control and experimental. Standard venom was injected i/p into control group of mice and the venom allocated from snakes, subjected to an irradiation at various modes was entered into experimental groups of mice. After envenoming of mice with vipera venom, oppression of condition was observed in all experimental animals, and they perished. However, lifespan fluctuated depending on the maintenance of the total protein and apparently from degree of toxicity of Venom. Studying of influence of electromagnetic radiation on toxicity of Venom Vipera lebetina obtusa was spent in experiment in several stages.

The subsequent groups of the mice subjected to electromagnetic radiation at high modes of an irradiation, were also divided into experimental and control groups. Simultaneously, vipera venom, allocated from snakes preliminary irradiated throughout 24 hours at high intensity of an electromagnetic field, (14000V) was 
injected in a dose of $0.2 \mathrm{mg} / \mathrm{g}$ to the first experimental group of animals.

Vipera venom, allocated from snakes preliminary irradiated throughout 24 hours at high intensity of an electromagnetic field $(15000 \mathrm{~V})$ was injected into the second experimental group of animals.

Vipera venom, allocated from snakes preliminary irradiated throughout 24 hours at high intensity of an electromagnetic field $(16000 \mathrm{~V})$ was injected into the third group of experimental animals. Vipera venom allocated from snakes preliminary irradiated throughout 24 hours at high intensity of an electromagnetic field $(17000 \mathrm{~V})$ was injected into the fourth group of experimental mice. Vipera venom, allocated from snakes preliminary irradiated throughout 24 hours at high intensity of an electromagnetic field $(18000 \mathrm{~V})$ was injected into the fifth group of experimental mice. Vipera venom, allocated from snakes preliminary irradiated throughout 24 hours at high intensity of an electromagnetic field (19000V) was injected into the sixth group of experimental mice. Vipera venom allocated from snakes preliminary irradiated throughout 24 hours at high intensity of an electromagnetic field $(20000 \mathrm{~V})$ was injected into the seventh group of experimental mice. Though identical changes of the general condition were observed at experimental group of mice which was injected with vipera venom, allocated from snakes preliminary irradiated throughout 24 hours at high intensity of an electromagnetic field (14000V-20000V), however in lifespan of mice the tendency to insignificant increase in term of life was marked. Deterioration of the general condition at all groups of mice also was observed already later 5-10 minutes.

Breath increase, infringement of coordination of movement was marked after injection of venom of vipera, irradiated at high intensity, first minutes after injection of venom in all mice. After 20-30 minutes a condition of experimental groups of mice worsened. Mice had dyspnea, slackness, puffiness. Further the condition of mice gradually worsened, and mice perished. Lifespan of experimental groups of mice corresponded to 45-61 minutes. The identical phenomena has been noted at experimental animals after injection of venom, irradiated with electromagnetic radiation both at modes low, and at high intensity of an irradiation. However lifespan at mice of all groups varied from 25 till 66 minutes.

Thus, comparing the obtained data to results of references it is possible to ascertain that appreciable reduction of toxicity of vipera venom was marked at an irradiation of snake venom in small doses of radiation scale. With increase in a dose of an irradiation, change of both physical and chemical properties of vipera venom, and therefore its toxicity and pharmacological activity is most likely marked. It is necessary to specify the advantage of an irradiation of vipera venom with electromagnetic radiation in comparison with a radiating irradiation. Minor alteration in lifespan of experimental mice was marked at low EMR, and high intensity, in comparison with a radioactive irradiation. From the above-stated follows that application of EMR for sterilization of snake venom and its preparations is preferable rather than application for the similar purposes of radiating sterilization.

It is necessary to notice that the change of quantity of the total protein in snake venom was not marked at an irradiation of snakes by electromagnetic radiation of low intensity. Toxicity of venom also wasn't exposed to changes. At high intensity of radiation, insignificant fluctuations in the maintenance of the total protein and change of toxicity of snake venom were observed. Influence of electromagnetic radiation on the maintenance of the total protein of standard samples of vipera venom was observed. We carried out experimental measurements on studying of influence of electromagnetic radiation on the maintenance of the total protein of vipera venom. In experiments a generator of the microwave oven (with frequency of 10-460 MHz) was radiation source. The irradiation of vipera venom was spent at modes high (U$14000 \mathrm{~V})$ and low (U-7000V) intensity of an irradiation throughout 30 minutes, 1 and 2 hours. Thus, target capacities of a radiator $-\mathrm{P}(70 \mathrm{Vt})$ were applied. Definitions of the maintenance of total protein in the samples of venom subjected to influence of EMR was defined by a method of Lowry.

From the given tables it is visible that under the influence of electromagnetic radiation of low intensity (U - 1000$7000 \mathrm{~V}$ ) throughout 30 minutes, 1 and 2 hours, minor alterations in the maintenance of total protein of venom were marked. The maintenance of protein in investigated samples of Venom fluctuates within $96.50 \pm 0.48-$ $95.00 \pm 1.90 \mathrm{mg} / \mathrm{g}$. At influence of EMR of high intensity (U-14000-20000V) throughout 30 minutes, 1 and 2 hours, considerable changes in quantity of the total protein of venom were marked in comparision with samples of the venom, subjected influence of EMR of low intensity.

The quantity of protein in investigated samples of vipera venom, under influence of EMR of high intensity fluctuates in limits $-96.10 \pm 3.64-90.00 \pm 3.79 \mathrm{mg} / \mathrm{g}$. Thus, on the basis of the carried out experimental researches it is possible to ascertain that under the influence of electromagnetic radiation of low intensity ( $U-1000 \mathrm{~V}$ $7000 \mathrm{~V})$, minor alterations in the maintenance of the total protein of venom were marked. At influence of EMR of high intensity (U-14000V-20000V) considerable changes were marked in quantity of the general fiber of Venom in comparison with samples of venom, subjected to EMR 
with low intensity of radiation. Apparently, these changes influence also on toxicity of snake venom. We drew absorption spectra in infra-red, visible and ultra-violet areas, standard venom and the samples of snake venom subjected selectively to influence of EMR of low intensity in limits $\mathrm{U}-1000 \mathrm{~V}-7000 \mathrm{~V}$ and high intensity in limits $\mathrm{U}-14000 \mathrm{~V}-20000 \mathrm{~V}$.
Measurements by definition of the maintenance of radionuclides in samples of venom of vipera, caught in districts of Azerbaijan with various degrees of impurity, and also in samples of soils, vegetation and water was conducted on spectrometer Canberra. Time of experiment was 24 hour. The spectrum defining activity of radionuclides in snake venom was drawn on a spectrometer "CANBERRA" (table 2).

Table. 2: Influence of vipera venom (irradiated with small doses of $\gamma$-radiation) on lifespan of mice (a dose of venom entered $\mathrm{i} / \mathrm{p}-0.2 \mathrm{mg} / \mathrm{g}$ )

\begin{tabular}{|l|l|l|l|}
\hline$\gamma$-irradiation dose, $\mathrm{KGy}$ & \multirow{2}{*}{$\begin{array}{l}\text { Duration of an irradiation } \\
\text { in hours }\end{array}$} & \multicolumn{2}{|l|}{ Lifespan of mice in minutes } \\
\cline { 3 - 4 } & 0.5 & Control & Experiment \\
\hline 1.35 & 1.0 & $28-36$ & $28-36$ \\
\hline 2.7 & 1.5 & $28-36$ & $45-60$ \\
\hline 4.05 & 2.0 & $28-36$ & $60-70$ \\
\hline 5.4 & \multicolumn{2}{|}{} \\
\hline
\end{tabular}

Thus, comparing the obtained data with results of references it is possible to ascertain that at an irradiation of venom with small doses of gamma radiation, appreciable reduction of toxicity of zootoxin was marked. With increase in a dose of an irradiation, change in both physical and chemical properties of vipera venom and its toxicity and pharmacological activity, as a general rule, was marked.

Thus, changes of toxicity of vipera venom under the influence of $\gamma$-radiation were established experimentally on 50 white not purebred mice at doses 2.7, 4.05, 5.4 кGy. From the above-stated it is possible to ascertain that influence of small doses of $\gamma$-radiation on toxicity and on pharmacological properties of venom of Vipera lebetina obtusa was revealed. The regularities in reduction of toxicity of venom was revealed at an irradiation by small doses of $\gamma$-radiation. It was experimentally established that with increase in a dose of radiation, reduction of toxicity of venom is accordingly observed.Essential change of toxicity of vipera venom was not noted under the influence of $\gamma$-radiation at a dose 1.35 кGy. Changes of toxicity of Vipera venom under the influence of gradiation were revealed at doses $2.7,4.05,5.4 \mathrm{\kappa Gy}$. The regularities in reduction of toxicity of venom at increase of a dose of $\gamma$ - irradiation was established by radiation.

Lifespan at mice of 1st group didn't differ from experimental groups of mice while it varied from 45 till 90 minutes at mice of 2 nd 3 and 4 th experimental groups. From the above-stated it is possible to ascertain that study of consequences of global anthropogenous pollution of biosphere and preservation of the environment are among the most actual and essential problems of the nowadays.
On the basis of the received data it is possible to ascertain that depending on degree of impurity of district where catching, milking of snakes, taking samples of vegetation and soils were conducted, fluctuations in the maintenance of heavy metals were marked. However, radiating activity of elements in snake venom and soils didn't change almost.

Thus, the influence of ecological factors (biotic, abiotic), on biochemical indicators, pharmacological and toxicological properties of Venom Caucasian Viperas was studied and optimum doses of radiating sterilization of Venom were established.

\section{CONCLUSIONS}

1. The method atom-absorbtcnion spectrophotometry (AAS-300, Perkin-Elmer) in vipera venom, caught from ecologically polluted sites of Absheron, defined the maintenance of heavy metals-pollutants. As a result, changes in chemical compound and also influence of heavy metals on protein structure, fermentative activity and other biochemical indicators of vipera venom were established.

2. Influences of intensity of electromagnetic radiation on protein structure, the maintenance of the general fiber and change of toxicity of venom of snakes were revealed.

3. Influence of the metals-pollutants, ionising radiation and electromagnetic radiation on biochemical parametres of vipera venom, on fermentative activity and toxicity of venom were experimentally revealed. Doses of radiations were determined and revealed for sterilization of both snake venom, and its water solutions. 
4. Influence of ecological factors (biotic, abiotic) on biochemical indicators, pharmacological and toxicological properties of Caucasian vipera Venom was studied and optimum doses of radiating sterilization of venom were determined.

5. The method of atom-absorbtion spectrophotometry (AAS-300, Perkin-Elmer) in vipera venom, caught from ecologically polluted sites of Absheron, defined the maintenance of heavy metals-pollutants.

Thus, in comparative aspect, the influence of ecological factors on venom of Transcaucasian viperas was revealed. Concentration of heavy metals in venom of vipera, caught in various biotopes of Azerbaijan, and also in vegetative and soil tests was defined. As a result, changes in chemical compound and also influence of heavy metals on protein structure, fermentative activity and other biochemical indicators of venom of viperas were established. The revealed values will be applied at preparation of preparations on the basis of venom of snakes. It will be in turn recommended for pharmaceutical industry by manufacture of injections on the basis of venom of snakes.

\section{REFERENCES}

[1] Ahunov A. Some physico-chemical and biological properties of venom proteases of the Central Asian vipera. // Uzb. Bio. Journal. - 1974, №2.- P. 75-76.

[2] Abiyev H.A., Topchiyeva Sh.A. Influence of small doses of radiation on spectral characteristics and pharmacological properties of venom transcaucasian viper- Vipera lebetina obtusa. Europen radiation research 2006, The 35 th Annual Meeting of the European Radiation Research Society and The 4 th Annual Meeting of the Ukrainian Society for Radiation Biology., Kiyev, Ukraine, 2006. - P. 223.

[3] Abiyev H.A., Topchiyeva Sh.A., Rustamov V.R. Radiating sterilization of the venom of snake.Fourth Euroasian Conference Nuclear science and its application, Bak1, 2006, P. 178.

[4] Barkagan Z.S., Valseva I.A., Mitelman L.Sh., Anticoagulating and toxic properties of Central Asian cobra venom.// Izvestia Akad. Biol., - 1967, №1.- P. 116-124.

[5] Barkagan Z.S, Suhoveeva E.Y., Shevchenko V.I. Results and prospects of application of snake venoms in the diagnosis of disorders in blood coagulation. Abstracts III All-Union Herpetological Conference/. - 1973. - P. 30-31.

[6] Berdiyeva A.T. Study of permeability of blood capillaries in snake venom poisoning by skin-trypan sample.// Izvestia TSSR Ser. Biol.,- 1962, №5. - P. 88-91.
[7] Valseva I.A., Pavlovski E.N., Talizin F.F.The influence of cobra venom on the central nervous system Akad,1962. - T. 145, №2. - P. 469-472.

[8] Ishaki Y.B. Effect of vipera venom on postoperative course in the extirpation of the tonsils. Bulletin of Otorhinolaryngology. - 1959, №5. - P. 44-47.

[9] Sh.A.Topchiyeva, H.A.Abiyev. Comparative effect of soil pollution of Absheron peninsula in Azerbaijan on the chemical composition of venom of Transcaucasian vipera -Vipera lebetina obtusa.Bilgi journal, Bakı. 2004, №4. - P. 74-78.

[10] Topchiyeva Sh.A., Abiyev H.A. The action of gamma irradiation on the spectral characteristics of vipera venom. // J. "Izvestia" NASA, Series of Biological Sciences, Baku 2006, №5-6. - P. 138143.

[11] Topchiyeva Sh.A., Abiyev H.A. The action of gamma irradiation on the spectral characteristics of vipera venom. // J. "Izvestia" NASA, Series of Biological Sciences, Baku 2006, №5-6. - P. 138143.

[12] Topchiyeva Sh.A., Abiyev H.A. Ecological factor's and chemical structure of venom of Vipera lebetina obtusa // J. Ecoenergenika, Baku, 2004, №1. - P. 21-23.

[13] Galán, J.A., Sánchez, E.E., Bashir, S., Pérez, J.C., Characterization and identification of disintegrins in Crotalus horridus venom by liquid chromatography and tandem matrix-assisted laser desorption ionization quadrupole ion trap time-of-fligh (MALDI-QIT-TOF) mass spectrometry. // Canadian J. Chem2005, 83, P. 1124-1131.

[14]Gasmi A., Karoui H., Adrit L., El. Ayeb M., Identification des compases toxiques dans les venins de Viperes Cerastes cerastes of Vipera lebetina: Purification des phospholipases. Arch. Inst. Pasteur Tunis, 1988, v. 65, No 1-2. - P. 43-52.

[15]Lomonte B., Lean G., Hanson L.A. Similar effectiveness of $F a b$ and $F(a b) 2$ antivenoms in the neutralization of hemorragic activity of vipera berus snake venom in mice.// J. Toxicon, 1996, v. 34, No 10. - P.1192-1202

[16] Sh. A. Topchiyeva, A. M. Magerramov, N. N. Musayeva, L.Z. Allaxverdiyeva, R. Z. Allaxverdiyeva, Abiyev H.A. Influence of small dozes gamma radiations on molecular mobility and pharmacological properties of venom of Vipera Lebetina Obtusa, 40 $0^{\text {th }}$ IUPOC International Symposium on Macromol, WORLD POLYMER CONGRESS MACRO. - Paris-France, 2004. - P. 5.3-120.

[17] Winkler E., Chovers M., Almog S. Decreased serum cholesterol level after snake bite (Viper palastinae) 
as a marker of severity of envenomation. // J. Lab. Clin. Med., 1993, v. 121, No 6. - P. 774-778.

[18] Boni-Mitake M., Costa H., P.J. Spencer, Vassilieff V.S., Rogero J.R.. Effects of ${ }^{60} \mathrm{Co}$ gamma radiation on crotamine.// Braz J Med Biol Res, 2001, Vol. 34(12). - P.1531-1538

[19] Mirco Jessica, Baptista Janaina A, Caproni Priscila, Yoshito Daniele, Nascimento do Nanci. Evaluation of miotoxic activity of bothropstoxin-1 irradiated with ${ }^{60} \mathrm{Co}$ gamma rays. // International Nuclear Atlantic Conference - INAC Rio de Janeiro,RJ, Brazil, 2009/ - P. 978-985.

[20] Samel M., Subbi J., Siigur J., Siigur E., 2002, Biochemical characterization of fibrinogenolytic serine proteinases from Vipera lebetina snake venom. // J. Toxicon, 40, (1). - P. 51-54.

[21] Sánchez, E.E., Ramírez, M.S., Galán, J.A. Cross reactivity of three antivenoms against North American snake venoms, // J.Toxicon, 2000, (241). - P. 315-320.

[22] Topchiyeva Sh.A. Chromatographic and spectral characteristics of snake venom, proteins and products of metabolism of ones.// J. Farmakom, Kharkov. 2002, (4).- P. 75-81.

[23] Topchiyeva Sh.A, Fluorescent probes in snake venom investigation.// J. Farmakom, Kharkov, 2002, (3). - P. 174.-179.

[24] Topchiyeva Sh.A., Iskenderov T.M., Jabbarov R.B., Musayeva N.N. Influence of the ecological factors to number Vipera lebetina obtusa and chemical composition of venom. Proceedings of the First International Conference on Environmental Research and Assessment. - Bucharest, Romania, 2003. P. 34-37. 